\title{
TEORI PROSPEK DAN KONSERVATISMA LAPORAN KEUANGAN
}

\author{
Muhamad Safiq ${ }^{1}$, Jogiyanto $\mathrm{HM}^{2}{ }^{2}$, Supriyadi ${ }^{3}$, dan Ertambang Nahartyo ${ }^{4}$ \\ ${ }^{1}$ Universitas Presiden, Cikarang dan ${ }^{2,3,4}$ Universitas Gadjah Mada, Yogyakarta \\ Email: safiq2006@gmail.com
}

\section{KETERANGAN ARTIKEL}

Riwayat Artikel

Diterima: 15 Mei 2019

Direvisi: 1 Juni 2019

Disetujui: 15 Juni 2019

Klasifikasi JEL

M4, M41

Keywords: Prospect Theory, Framing Effect, Certainty Effect, Financial Reporting

Kata Kunci: Teori Prospek, Framing Effect, Certainty Effect, Pelaporan Keuangan

\section{ABSTRACT}

This research was aimed to test the influence of incentive contract framing (framing effect) and class action (certainty effect) to financial reporting decision. Beside that, this research also investigated the interaction influence between framing effect and certainty effect. This research used laboratorium experiment design $2 \times 2$ between subjects. Experiment subjects were business students (MM and Maksi) Gadjah Mada University who were acted as management (CFO) with certain criteria. Research results showed that there was an influence of incentive contract framing and class action (litigation) to management's (CFO) financial reporting decision. Subjects who were the insentive contract framed positively, tended to prepare more conservative financial statement. Vice versa, subjects who were the incentive contract framed negatively, tended to become risk taker, so that management (financial director) tended to prepare less conservative financial statement. But, the interaction result between incentive contract framing variable with class action (litigation) showed insignificant result. measurement problems are thought to affect these insignificant. Future studies are expected to give more attention to these problems.

\section{ABSTRAK}

Penelitian ini bertujuan untuk menguji pengaruh pembingkaian kontrak insentif (framing effect) dan class action (efek kepastian) terhadap keputusan pelaporan keuangan. Selain itu, penelitian ini juga meneliti pengaruh interaksi antara efek pembingkaian dan efek kepastian. Penelitian ini menggunakan desain eksperimen laboratorium $2 \times 2$ antar subjek. Subjek yang digunakan adalah mahasiswa bisnis (MM dan Maksi) Universitas Gadjah Mada yang bertindak sebagai manajemen (CFO) dengan kriteria tertentu. Hasil penelitian menunjukkan bahwa ada pengaruh pembingkaian kontrak insentif dan class action (litigasi) terhadap keputusan pelaporan keuangan manajemen (CFO). Subjek yang kontrak insentifnya dibingkai positif, cenderung menyajikan laporan keuangan yang lebih konservatif. Begitu pula sebaliknya, subyek yang kontrak insentifnya dibingkai negatif, cenderung menjadi pengambil keputusan yang berisiko, sehingga manajemen (CFO) cenderung menyajikan laporan keuangan yang kurang konservatif. Namun, hasil interaksi antara variabel pembingkaian kontrak insentif dengan class action (litigasi) menunjukkan hasil yang tidak signifikan. Mungkin karena masalah pengukuran yang harus mendapat perhatian lebih. 


\section{PENDAHULUAN}

Isu konvergensi International Financial Reporting Standard (IFRS) telah berlangsung dalam beberapa tahun terakhir. Isu tersebut melanda seluruh negara di dunia. Hal itu tidak lepas dari keinginan sebagian stakeholder, khususnya investor atau pebisnis yang menginginkan laporan keuangan suatu perusahaan yang mencerminkan kondisi keuangan perusahaan yang sebenarnya dan dipahami dengan baik serta dapat diperbandingkan. Hal itu telah menjadi kajian yang cukup lama oleh International Accounting Standard Board (IASB, 2006) yang berwenang menerbitkan sebuah standar (IFRS) yang dapat diterima dan dibutuhkan oleh investor dan calon investor di seluruh dunia. Melalui laporan keuangan yang berbasis IFRS, investor dan calon investor dapat memilih tempat investasi tanpa harus takut dengan regulasi yang berlaku di suatu negara.

Ide IASB untuk mengembangkan IFRS, yang mana IFRS memiliki keunikan yang cukup menonjol perbedaannya dengan standar yang digunakan sebelumnya, misalnya US GAAP atau SAK untuk di Indonesia, bertujuan untuk mengatasi beberapa kelemahan yang terdapat dalam standar sebelumnya. Seperti telah dikemukakan sebelumnya oleh para praktisi, peneliti, dan akademisi bahwa standar akuntansi saat itu sangat mengedepankan prinsip konservatisma, yang mana prinsip tersebut berdampak pada pelaporan laba dan aset bersih bersih perusahaan yang relatif lebih rendah dari nilai pasarnya (Ahmed et al., 2000; Beaver dan Ryan, 2005). Akibatnya, beberapa stakeholder, diantaranya investor dan pemilik perusahaan, merasa dirugikan dengan adanya prinsip tersebut. Oleh karena itu, mereka sangat antusias terhadap penerbitan standar akuntansi yang baru, yaitu standar yang berbasis IFRS.

Selanjutnya, apa yang menyebabkan mereka antusias menyambut penggunaan IFRS dalam pelaporan keuangan? Antusiasme beberapa stakeholder dalam penggunaan standar yang berbasis IFRS tersebut tidak lepas dari penggunaan kebijakan principle based dari sebelumnya yaitu rule based, ketika menentukan angka-angka akuntansi yang akan disajikan dalam laporan keuangan. Rule based, yang mengatur sangat ketat dalam menggunakan metode dan kebijakan akuntansi oleh manajemen ketika menyajikan laporan keuangan, hanya memberi ruang yang relatif kecil bagi manajemen dalam membuat kebijakan akuntansi. Lebih dari itu, standar akuntansi yang ada cenderung menyebabkan nilai aset dan laba lebih rendah, misalnya PSAK 34 yang menyebutkan bahwa pendapatan kontrak konstruksi diakui bila terdapat kondisi yang dapat diestimasi secara andal, sedangkan biaya harus segera diakui meskipun baru bersifat indikasi. Sebaliknya, principle based cenderung memberikan keleluasan yang lebih besar bagi manajemen dalam mengambil kebijakan akuntansi ketika menyajikan laporan keuangan. Kebijakan akuntansi tersebut cenderung digunakan manajemen untuk menilai aset-aset yang berada pada level 2 dan 3 yang tidak memiliki harga pasar atau memiliki harga pasar yang sangat terbatas, sehingga membutuhkan judgment manajemen. Akibatnya, nilai aset yang membutuhkan judgment manajemen tersebut dapat dilaporkan lebih tinggi atau lebih rendah dari nilai pasarnya atau nilai bukunya.

Dengan demikian, niat IASB untuk mengadopsi keinginan beberapa stakholder perusahaan dengan mengubah rule based ke principle based agar aset yang dilaporkan sesuai dengan nilai pasarnya dapat dipertanyakan. Hal itu juga menjadi concern Hellman (2008) dan Watts (2003ab). Hellman (2008) melaporkan bahwa IFRS masih tetap menggunakan prinsip konservatisma dalam penilaian aset bersih perusahaan, meskipun dengan sedikit perubahan yaitu dari konservatisma yang bersifat permanen ke konservatisma yang temporer. Sedangkan, Watts (2003ab) mengkritisi pemberian ruang yang lebih luas bagi manajemen untuk membuat kebijakan akuntansi, akibat perubahan dari rule based ke principle based. 
Dengan memberikan keleluasaan yang luas kepada manajemen dalam membuat judgment akuntansi, maka hal itu dapat meningkatkan moral hazard manajemen yang pada akhirnya dapat merugikan stakeholder yang lebih besar.

Namun, hasil penelitian mengenai konservatisma akuntansi cenderung kurang konsisten karena peneliti memiliki fleksibilitas untuk mendefinisikan dan mengklasifikasikan konservatisma akuntansi. Akibatnya, ada beberapa definisi dan ukuran yang berbeda yang memungkinkan hasil yang berbeda dalam penelitian ini. Hal itu menjadi motivasi penulis untuk mengembangkan lebih lanjut penelitian mengenai konservatisma. Selain itu, penulis akan menggunakan teori prospek (Kahneman dan Tversky, 1979) untuk menjelaskan pengaruh psikologis manajemen dalam menyajikan laporan keuangan. hal itu menjadi motivasi berikutnya penulis dalam penelitian ini. Penggunaan teori prospek dalam penelitian ini tidak lepas dari kekuatan teori yang telah teruji di berbagai bidang seperti politik, hukum, kedokteran, dan sebagainya. Penjelasan teori prospek mengenai pengaruh psikologis dalam pengambilan keputusan yang begitu baik mendorong penulis untuk mengujinya dalam ranah akuntansi. Beberapa penjelasan teori prospek sangat tepat untuk menjelaskan pengaruh factor psikologis dalam pelaporan keuangan, tak terkecuali dalam pengambilan keputusan di ranah akuntansi.

Oleh karena itu, penulis tertarik untuk menguji penjelasan teori teori dengan tujuan antara lain pertama, untuk mengetahui pengaruh teori prospek melalui penjelasan framing effect dalam pelaporan keuangan. Kedua, untuk mengetahui pengaruh teori prospek melalui penjelasan certainty effect dalam pelaporan keuangan. Terakhir, untuk mengetahui pengaruh interaksi antar penjelasan teori prospek yaitu framing effect dan certainty effect.

\section{KAJIAN LITERATUR DAN PENGEMBANGAN HIPOTESIS \\ Teori Prospek}

Ada beberapa penjelasan yang diperkenalkan untuk menjelaskan teori prospek. Kahneman dan Tversky (1979) adalah penulis pertama yang memperkenalkan teori prospek. Mereka mengembangkan teori prospek untuk menjelaskan alasan seseorang membuat keputusan tertentu dari sisi psikologisnya. Teori prospek membantah teori sebelumnya yang menjelaskan bahwa keputusan yang diambil seseorang bersifat rasional dan linear, expected utility theory. Melalui beberapa penjelasanya, antara lain framing effect, certainty effect, insurance effect, dan endowment effect. Penjelasanpenjelasan tersebut terbukti mampu menjelaskan alasan seseorang membuat keputusan tertentu dalam berbagai bidang, antara lain politik, kedokteran, psikologi, hukum, dan sebagainya.

Sebagai sebuah teori yang menekankan pada faktor psikologis, teori prospek menyatakan bahwa dalam membuat keputusan individu-individu cenderung fokus pada prospeknya, yaitu prospek gains dan prospek losses, bukan pada total kekayaan. Adapun, yang digunakan sebagai titik referensinya (reference point) dalam menghitung laba (gain) dan rugi (loss) selalu berubah dari waktu ke waktu. Selanjutnya, seseorang atau pembuat keputusan mempersepsikan munculan atau prospek (outcomes) dalam bentuk fungsi nilai. Hal itu sesuai dengan kesimpulan utama Kahneman dan Tversky (1979) yang menjelaskan bahwa fungsi nilai didefinisikan dalam bentuk gains dan loss. Fungsi nilai menjelaskan bahwa dalam membuat keputusan individu cenderung risk averse ketika berada dalam domain laba (gain) dan risk seeking ketika berada pada domain rugi (loss). Fungsi nilai loss digambarkan dengan kurva yang lebih cekung dan curam, sedangkan fungsi nilai gain digambarkan dalam bentuk kurva cembung dan tidak begitu curam. 
Perbedaan bentuk kedua gambar tersebut berimplikasi pada hasil yang sangat penting. Selanjutnya, fungsi nilai individu tersebut memenuhi properti-properti yang nampak dalam gambar berikut.

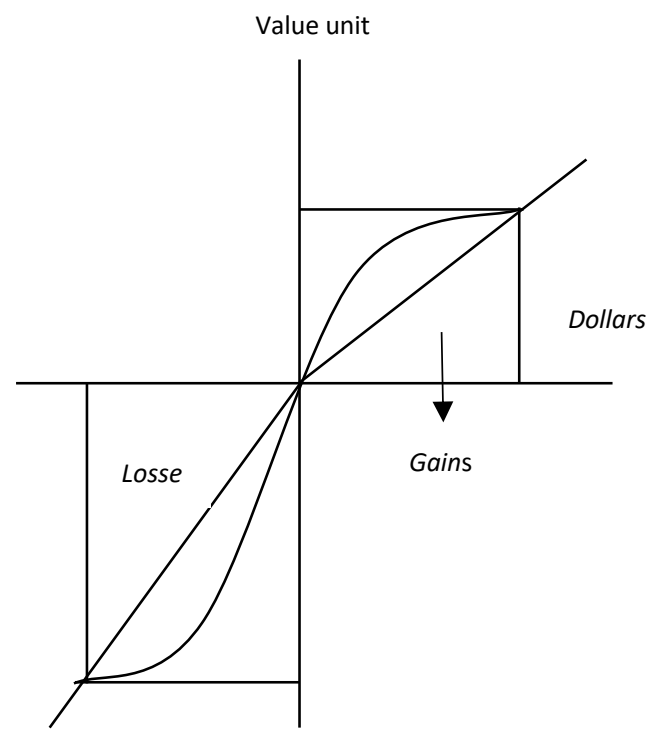

Gambar 1. Fungsi Nilai Teori Prospek

Sumber: Kahneman dan Tversky (2003)

Dalam Gambar 1 menjelaskan bahwa ada beberapa hal yang terkait dengan fungsi nilai pembuat keputusan, antara lain pertama, fungsi nilai tersebut didefinisikan dalam laba (gain) dan rugi (loss) daripada kesejahteraan total (total wealth). Kedua, kurva yang berada diatas garis horizontal berbentuk cembung yang menunjukkan domain gain dan kurva yang berada dibawah garis horizontal berbentuk cekung yang menunjukkan domain loss. Ketiga, bentuk kurva yang cekung dan curam menunjukkan domain loss daripada domain gain yang cenderung landai (Kahneman dan Tversky, 2003: p.3). Lebih lanjut, hal itu menjelaskan bahwa fungsi nilai dalam kurva rugi (loss) dirasakan lebih menyakitkan daripada kepuasan yang diperoleh dari keuntungan (gain), meskipun dengan jumlah yang sama. Implikasinya, pembuat keputusan cenderung enggan berisiko (risk averse) dalam mengambil keputusan ketika pilihan berada antara gain dan loss. Dengan kata lain, teori prospek menunjukkan bahwa seseorang cenderung membuat keputusan relatif kurang berisiko ketika berada dalam domain gain dan lebih berisiko (risk taker) ketika berada dalam domain rugi (loss).

\section{Efek Pembingkaian (Framing effect)}

Beberapa penelitian sebelumnya telah melaporkan adanya pengaruh pembingkaian (framing) dalam pengambilan keputusan. Penjelasan pembingkaian dalam teori prospek berkaitan dengan cara penyajian masalah atau informasi. Pada umumnya, masalah atau informasi disajikan dalam bentuk gain (positif) atau loss (negatif). Penyajian informasi dalam bentuk gain dan loss merupakan model teori prospek yang menggunakan penjelasan framing (Kahneman \& Tversky, 1979; Tversky \& Kahneman, 1981). Informasi yang dibingkai positif atau negatif tanpa mengubah makna normatifnya digunakan untuk mempengaruhi pemakainya dalam mengambil keputusan. Pengambil keputusan yang diberikan informasi dengan bingkai positif mungkin akan membuat keputusan yang berbeda dengan yang diberikan informasi dengan bingkai negatif. Informasi yang dibingkai secara positif (gain) mempengaruhi pengambil keputusan untuk membuat keputusan yang kurang berisiko (risk averse). Sebaliknya, pembuat keputusan yang diberi informasi yang dibingkai secara negatif (loss) cenderung akan membuat keputusan yang lebih berisiko (risk seeking), sebagaimana yang didokumentasikan Kahneman dan Tversky (1979).

Hasil penelitian mengenai pembingkaian dalam pelaporan keuangan dilakukan melalui pemilihan metode akuntansi tertentu. Healy dan Palepu (1993) mendokumentasikan bahwa diskresi yang dimiliki manajer memungkinkan manajer tersebut melakukan pembingkaian terhadap laporan tahunan yang disajikan. Hal itu dilakukan dalam rangka mengkomunikasikan informasi privatnya kepada investor dan pengguna laporan keuangan lainnya melalui format yang 
berbeda. Selain itu, pembingkaian juga dapat dilakukan untuk memenuhi tujuan tertentu, misal untuk tujuan yang kurang baik yaitu membingkai laporan keuangan yang dapat menyesatkan para penggunanya (misal kecurangan) melalui representasi yang berbeda (Johnson et al., 1991). Hal itu menunjukkan bahwa pembingkaian dapat menjadi sumber bias yang dapat menyesatkan pengambil keputusan. Selanjutnya, Jamal et al. (1995) mendokumentasikan pengaruh framing dalam pelaporan keuangan yang mendukung Kahneman dan Tversky (1986). Mereka menjelaskan bahwa laporan keuangan yang dibingkai dapat dideteksi dengan cara mengubah suatu masalah kedalam representasi standar. Dengan menggunakan cara yang dijelaskan Kahneman dan Tversky (1986), yaitu multiple representation dan representasi standar diperoleh bahwa auditor yang menggunakan representasi standar sukses mendeteksi adanya pembingkaian yang dilakukan manajemen, agregasi item, serta mampu mendeteksi kecurangan. Hal itu ditemukan dengan melalui empat kasus yang digunakan dalam penelitiannya.

Selanjutnya, framing effect dikatakan terjadi bila dilakukan perubahan deskripsi tugas, namun tidak mengubah makna secara normatifnya, dapat mengubah keputusan yang dibuat oleh pengambil. Kahneman \& Tversky (1986) mengemukakan bahwa framing merupakan fenomena kognitif umum dan keputusan beragam yang diambil oleh individu cenderung dipengaruhi oleh cara informasi tersebut disajikan. Luft (1994) mendokumentasikan bahwa karyawan lebih suka menerima kontrak insentif dalam bentuk bonus daripada kontrak yang identik dengan pinalti. Selanjutnya, judgment karyawan terhadap kinerja masa lalu tergantung pada daya ingat, preferensi terhadap kontrak bonus lebih tinggi daripada kontrak pinalti. Hannan et al. (2005) dan Church et al. (2008) mendukung temuan Luft tersebut. Hannan et al. (2005) melaporkan bahwa pada umumnya karyawan lebih menyukai kontrak bonus daripada kontrak pinalti. Loss aversion menyebabkan karyawan mengeluarkan upaya yang lebih besar ketika berada dalam kontrak pinalti daripada dalam kontrak bonus, meskipun ekuivalen secara ekonomi. Karyawan lebih enggan membayar denda (pinalti) daripada tidak menerima bonus, dan akibatnya mereka memilih level upaya yang lebih tinggi dalam kontrak pinalti untuk menghindari pembayaran denda.

Selanjutnya, manajemen, dalam hal ini direktur keuangan, yang paling bertanggungjawab terhadap pelaporan keuangan perusahaan, memiliki fleksibilitas untuk memilih dan membuat kebijakan akuntansi tertentu. PSAK pasca konvergensi masih mengindikasikan adanya penggunaan konservatisma akuntansi. Implikasinya, direktur keuangan dapat memilih metode dan kebijakan akuntansi sesuai dengan informasi yang ingin disampaikan. Adanya bukti tentang pengaruh kesejahteraan manajemen dalam memilih metode akuntansi dilaporkan Lubberink dan Huijgen (2001). Penjelasan mereka terhadap hasil penelitiannya menyebutkan bahwa sikap risiko eksekutif yang heterogen mempengaruhi derajat konservatisma. Manajer yang risk averse cenderung melaporkan laba yang lebih konservatif daripada manajer yang risk taker.

Berdasarkan penjelasan di atas, maka peneliti menduga bahwa manajemen (direktur keuangan) yang kontrak insentifnya dibingkai positif membuat ia cenderung risk averse dan membuat keputusan yang lebih konservatif daripada manajemen (direktur keuangan) yang kontrak insentifnya dibingkai negatif. Oleh karena itu, penulis merumuskan hipotesis yang akan diuji dengan pernyataan sebagai berikut.

$\mathrm{H} 1$ : Manajemen (direktur keuangan) cenderung menyajikan laporan keuangan yang lebih konservatif ketika mendapat kontrak insentif yang dibingkai positif daripada kontrak insentif yang dibingkai negatif (loss). 


\section{Efek Kepastian (Certainty effect)}

Efek kepastian (certainty effect) merupakan penjelasan berikutnya dari teori prospek (Kahneman dan Tversky, 1979). Berdasarkan beberapa problem yang disajikan, Kahneman dan Tversky (1979) menjelaskan bahwa seseorang cenderung memberikan bobot yang berbeda terhadap munculan (outcome) yang bersifat pasti dan munculan yang tidak pasti. Seseorang cenderung memberikan bobot kepastian dengan nilai yang lebih besar (untuk hasil yang positif) meskipun nilainya kecil daripada hasil yang lebih besar tetapi belum pasti (masih bersifat mungkin). Sedangkan, untuk kerugian (loss), seseorang akan memilih kerugian yang besar tetapi belum pasti daripada kerugian kecil tetapi pasti. Hal inilah yang menjadikan concern Kahneman \& Tversky (1979) dalam membantah expected utility theory yang telah dikenal sebelumnya.

Sitkin dan Weingart (1995) melaporkan bahwa risiko persepsian berhhubungan negatif dengan keputusan berisiko. Hal itu konsisten dengan teori prospek. Temuan tersebut menjelaskan bahwa sikap menghindari risiko lebih besar ketika ada ancaman terhadap aset (dipersepsikan berisiko tinggi) daripada dipersepsikan berisiko kecil, meskipun belum terjadi kerugian. Hasil selanjutnya juga mengindikasikan bahwa semakin tinggi tingkat risiko berhubungan negatif dengan pengambilan keputusan yang berisiko karena individu cenderung menghubungkan risiko dengan munculan negatif yang lebih kuat daripada dengan variabilitas munculan.

Hasil penelitian lainnya menunjukkan bahwa adanya hubungan positif antara kos litigasi ekspektasian dengan konservatisma laporan keuangan (Liu dan Thornton, 2008). Mereka menemukan adanya hubungan negatif antara price to book ratio (PBR) dengan asymmetric timeliness sebagai ukuran konservatisma laporan keuangan. PBR yang rendah merupakan proksi kos litigasi ekspektasian yang lebih tinggi dan laporan keuangan yang konservatif mengindikasikan sikap manajemen (direktur keuangan) yang cenderung hati-hati atau kurang berisiko. Sebelumnya, Watts (2003), Kothari et al. (1988), and Beaver (1993) mendokumentasikan bahwa konservatisma menurunkan biaya litigasi ekspektasian. Hal itu dikarenakan investor mungkin akan melakukan tuntutan hukum ketika laba atau net aset dinyatakan lebih besar (overstated) daripada ketika laba atau net aset dinyatakan lebih rendah (understated). Pernyataan laba dan aset bersih yang berlebihan memungkinkan investor melakukan tuntutan hukum terhadap perusahaan. Kemungkinan investor salah atau tidak tepat dalam memprediksi kinerja perusahaan yang akan datang akibat dari laporan laba dan aset bersih yang berlebihan daripada yang lebih rendah. Auditor dan manajemen perusahaan dapat menjadi pihak yang harus bertanggung jawab terhadap kerugian tersebut, sehingga mereka harus mengganti dugaan adanya kerugian. Selanjutnya, penggantian atas dugaan kerugian yang dituntut oleh investor dirasarkan sebagai bentuk disutilitas dan manajemen akan berusah dengan keras untuk menghindari disutilitas tersebut.

Oleh karena itu, sebagai konsekuensi dari upaya manajemen dalam menghindari disutilitas yang dirasakan oleh investor tersebut, maka manajemen (direktur keuangan) akan membuat kebijakan akuntansi yang dapat menghindari hal tersebut dengan membuat kebijakan akuntansi yang konservatif ketika menyajikan laporan keuangan. oleh karena itu, hipotesis uji dalam penelitian ini dinyatakan sebagai berikut.

H2: Ketika ada tuntutan hukum, manajemen (direktur keuangan) cenderung menyajikan laporan keuangan yang lebih konservatif daripada ketika tidak ada tuntutan hukum

Selain menguji pengaruh kedua hipotesis utama tersebut, penelitian ini juga melakukan interaksi terhadap kedua variabel tersebut. Efek interaksi merupakan pengaruh dua variabel independen atau lebih secara 
bersama-sama terhadap satu variable dependen dalam suatu penelitian. Adapun, bentuk pengaruh bersama-sama dua variable atau lebih terhadap satu variable dependen dapat berbentuk macam-macam, misalnya pemoderasian (moderating), pemediasian (mediating) atau intervening. Moderasi terjadi bila kekuatan hubungan antara dua variable (independen dan dependen) tergantung pada variable ketiga (moderator). Sedangkan, moderator merupakan variabel yang mempengaruhi arah dan atau kekuatan hubungan antara suatu variable independen dan satu variable dependen (Baron dan Kenny, 1986).

Selanjutnya, teori prospek juga menjelaskan tentang reflection effect (Kahneman dan Tversky, 1979). Reflection effect menjelaskan mengenai preferensi antara prospek positif dan negatif. Refleksi prospek akan terjadi di sekitar angka 0 , yang selanjutnya akan membalikkan urutan preferensi tersebut. Hal itu menunjukkan bahwa bila suatu prospek positif diubah dengan prospek negatif, maka akan terjadi perubahan preferensi yang berkebalikan. Adapun dampak dari reflection effect yaitu sikap risk aversion dalam domain positif yang disertai dengan sikap negatif dalam domain loss, maka individu akan mau menerima risiko yang lebih besar. Hal itu dapat dijumpai dalam kehidupan sehari-hari, termasuk oleh pengelola perusahaan.

Berdasarkan uraian tersebut, penulis mengajukan hipotesis interaksi dalam penelitian ini dengan menyatakan sebagai berikut.

H3: Manajemen (direktur keuangan) dengan kontrak insentif yang dibingkai positif dan ada ketidakpastian hasil akan membuat menyajikan laporan keuangan yang kurang konservatif daripada manajemen (direktur keuangan) yang mendapat kontrak insentif yang dibingkai negatif dan ada kepastian hasil

\section{METODE PENELITIAN}

Desain Penelitian

Untuk menguji hipotesis yang diajukan, penelitian ini menggunakan metoda eksperimen dalam pengumpulan datanya. Eksperimen merupakan desain riset untuk menginvestigasi suatu fenomena dengan cara merekayasa keadaan atau kondisi lewat prosedur tertentu dan kemudian mengamati hasil perekayasaan tersebut serta menginterpretasikannya (Nahartyo, 2012). Adappun desain eksperimen yang digunakan dalam penelitian ini yaitu desain faktorial $2 \times 2$ between subject. Dalam sebuah penelitian yang menggunakan eksperimen, ada dua hal yang menjadi perhatian utama dalam desainnya, yaitu pertama, valid secara internal, dan kedua, valid secara eksternal. Namun demikian, desain penelitian eksperimen lebih menekankan pada validitas internal. Validitas internal diperlukan untuk mendukung kesimpulan kausalitas yang diklaim oleh peneliti. Untuk melihat lebih jelas mengenai desain eksperimen penelitian ini, maka dapat dilihat dalam tabel berikut ini.

Tabel 1. Tabel kontinjensi desain eksperimen

\begin{tabular}{lcc}
\hline & $\begin{array}{c}\text { Pembingkan } \\
\text { kontrak } \\
\text { insentif } \\
\text { positif }\end{array}$ & $\begin{array}{c}\text { Pembingkan } \\
\text { kontrak } \\
\text { insentif } \\
\text { negatif }\end{array}$ \\
\hline $\begin{array}{l}\text { Ada } \\
\text { tuntutan } \\
\text { hukum }\end{array}$ & 1 & 2 \\
\hline $\begin{array}{l}\text { Tidak ada } \\
\text { tuntutan } \\
\text { hukum }\end{array}$ & 3 & 4 \\
\hline
\end{tabular}

\section{Subjek}

Subjek eksperimen yang digunakan dalam penelitian ini harus memenuhi kriteria yang telah ditetapkan sebelumnya, yaitu mahasiswa bisnis (mahasiswa yang berasal dari program Maksi dan MM) dan berlatar belakang Sarjana Strata 1 Akuntansi. Selanjutnya, subject penelitian ini berasal dari mahasiswa program 
Magister Akuntansi dan mahasiswa program Magister Manajemen Universitas Gadjah Mada.

Ada pun alasan pemilihan mahasiswa sebagai subjek dalam eksperimen ini karena pertama, penulis menghadapi kendala (diantaranya keterbatasan waktu, biaya, sulit mendapatkan pelaku yang sesungguhnya), dan kedua penulis berpendapat bahwa keputusan yang dibuat oleh mahasiswa (dengan kriteria tertentu) tidak berbeda dengan keputusan pelaku sebenarnya (Hofstedt, 1972; dan Ashton dan Kramer, 1980).

Selanjutnya, rencana jumlah subjek yang dibutuhkan dalam eksperimen sebanyak 60 orang untuk mengisi 4 sel (masing-masing sel diisi 15 orang) sesuai dengan desain eksperimen. Hair et al. (1998) menjelaskan dalam bukunya mengatakan bahwa jumlah minimum subjek yang digunakan untuk mengisi tiap sel adalah 20, namun $5-10$ sampel dapat dibenarkan untuk jenis riset tertentu. Sedangkan, Sekaran (2003) mengatakan bahwa untuk kesuksesan riset eksperimen sederhana yang penuh dengan kontrol yang ketat, ukuran sampel 10-20 tiap selnya dapat dimungkinkan. Namun, setelah melalui proses seleksi dan cek manipulasi maka hanya 54 orang atau subjek yang datanya dapat digunakan dalam eksperimen ini.

\section{Variabel Penelitian \\ Variabel Terikat (dependent variable)}

Adapun variabel dependen dalam penelitian ini yaitu keputusan manajemen (direktur keuangan) mengenai judgment yang digunakan dalam memilihan metode atau kebijakan akuntansi. Variabel ini diukur dengan menggunakan skala $1-9$ untuk melihat kecenderungan direktur keuangan dalam memilih metode atau kebijakan akuntansi. Skor 1 mengindikasikan bahwa direktur keuangan cenderung mengambil kebijakan akuntansi yang menghasilkan biaya skecil-kecilnya, sedangkan skor 9 yang mencatat biaya sebesarbesarnya.

\section{Variabel Bebas (independent variable)}

Variabel independen penelitian ini ada 2 yaitu 1) pembingkaian kontrak insentif (bonus), dan 2) tuntutan hukum. Pembingkaian kontrak insentif yaitu kontrak insentif yang disajikan atau dijelaskan kepada CFO dengan terlebih dahulu dilakukan pembingkaian. Bingkai positif dilakukan dengan menonjolkan isi kontrak secara positif, sedangkan bingkai negative menonjolkan isi kontrak secara negative. Kemudian, tuntutan hokum merupakan suatu kondisi menunjukkan adanya tuntutan hokum atau tidak dalam kasus yang disajikan. Kedua variable dependen tersebut masing-masing memiliki dua level, yaitu pembingkaian kontrak insentif positif (gain) dan pembingkaian kontrak insentif negatif (loss). Sedangkan, variable biaya tuntutan hukum juga terdiri atas dua level, yaitu tuntutan hukum tinggi dan tuntutan hukum rendah. Baik variable pembingkain kontrak insentif maupun variable tuntutan hukum, kedua variable tersebut diukur dengan bilangan binomial 0 dan 1 . Angka 1 menunjukkan pembingkaian kontrak insentif positif dan ada tuntutan hukum, sedangkan angka 0 menunjukkan pembingkaian kontrak insentif negatif dan tidak ada tuntutan hukum.

\section{Material Kasus dan Prosedur Eksperimen}

Eksperimen ini menggunakan kasus yang dikembangkan sesuai dengan fenomena dan kondisi yang ada di Indonesia. Material kasus berisi mengenai informasi tentang kondisi keuangan perusahaan, kondisi lingkungan bisnis saat ini, serta informasi kualitatif lainnya mengenai perusahaan. Ada 2 material kasus yang dikembangkan dalam eksperimen ini yang selanjutnya digunakan sebagai tritmen, yaitu kasus tentang pembingkaian kontrak insentif dan kasus mengenai tuntutan hukum. Kedua kasus atau tritmen tersebut masing-masing memiliki 2 (dua) level, yaitu pembingkaian kontrak insentif positif dan pembingkaian kontrak insentif negatif, serta ada tuntutan hukum, dan tidak ada tuntutan hukum, 
sehingga sel yang terbentuk berjumlah 4 (empat) sel.

Fokus dari kasus yang digunakan eksperimen ini yaitu mengenai potensi penurunan pendapatan dan kebijakan akuntansi untuk mencatat biaya riset dan pengembangan oleh manajemen (direktur keuangan). Seperti diketahui bahwa direktur keuangan memiliki fleksibilitas untuk memilih dan membuat kebijakan akuntansi tertentu ketika menyajikan laporan keuangan, khususnya membuat kebijakan atau judgment besarnya biaya riset dan pengembangan. Hal itu sesuai dengan PSAK No. 19 yang memberikan keleluasaan untuk menggunakan judgment dalam menentukan besarnya biaya riset dan pengembangan.

Untuk kasus 2, penulis menggunakan kasus yang berkaitan dengan kemungkinan perusahaan dituntut di pengadilan karena penurunan harga saham perusahaan yang sangat signifikan, sehingga Bapepam-LK perlu melakukan suspensi terhadap saham perusahaan tersebut. Kemudian, masyarakat (investor) menilai bahwa penurunan harga saham yang sangat signifikan tersebut diduga karena kesalahan manajemen dalam menyajikan laporan keuangan, khususnya terkait dengan penilaian aset dan laba yang terlalu tinggi atau berlebihan (overstatement) sebelum melakukan IPO. Kebijakan mengenai hal itu dijelaskan dalam PSAK No. 57.

Selanjutnya, penulis atau eksperimenter menjelaskan aturan main dalam eksperimen yang diikuti pemberian tugas kepada subjek. Pertama, subjek diminta untuk berperan sebagai direktur keuangan yang memiliki tanggungjawab utama menyajikan laporan keuangan. Kedua, subjek ditugaskan secara random kedalam tiap-tiap sel sesuai dengan desain yang direncanakan yaitu empat sel. Randomisasi ini dilakukan melalui penyusunan kasus secara acak ke dalam empat model atau kombinasi sesuai dengan jumlah sel dalam desain eksperimen. Selain itu, eksperimenter juga mengacak sedemikian rupa tumpukan material kasus tersebut sehingga semua tersusun secara acak. kasus material yang sudah teracak tersebut kemudian dibagikan kepada subjek. Dengan demikian, setiap partisipan memiliki kemungkinan yang sama untuk mendapatkan salah satu material kasus dari empat kombinasi yang ada. Adapun susunan kasus yang mungkin diterima oleh masing-masing subjek antara lain 1) pembingkaian kontrak insentif positif dengan ada tuntutan hukum, 2) pembingkaian kontrak insentif positif dengan tidak tuntutan hukum, 3) pembingkaian kontrak insentif negatif dengan ada tuntutan hukum, dan 4) pembingkaian kontrak insentif negatif dengan tidak ada tuntutan hukum.

Langkah selanjutnya, eksperimenter membagikan booklet yang berisi kasus-kasus yang digunakan sebagai perlakukan kepada subjek. Subjek diminta untuk membaca kasus satu dengan hati-hati dan teliti terhadap setiap informasi yang disajikan. Kasus satu berkaitan dengan pembingkaian kontrak insentif yang berisi tentang dampak judgment terhadap jumlah insentif yang akan diterima oleh manajemen (direktur keuangan). Bagian ini digunakan untuk melihat pengaruh pembingkaian kontrak insentif terhadap keputusan pemilihan metode dan kebijakan akuntansi direktur keuangan ketika menyajikan laporan keuangan. Semua informasi yang disajikan dalam kasus berkaitan dengan kondisi perusahaan yang saat ini jabatan direktur keuangannya sedang anda perankan. Informasi yang disajikan bersifat kuantitatif maupun kualitatif, serta masalah pelaporan keuangan yang sedang dihadapi oleh CFO. Kasus ini juga berisi informasi mengenai kemungkinan tidak tercapainya target laba yang dibebankan kepada anda (manajemen/direktur keuangan). Anda memiliki kewenangan untuk menggunakan kebijakan akuntansi tertentu dalam mencatat biaya riset dan pengembangan. Setiap kebijakan akuntansi yang diambil dapat mempengaruhi laba yang dilaporkan dan insentif yang akan diterimanya. 
Setelah selesai membaca kasus, subjek diminta untuk menjawab pertanyaan yang akan digunakan untuk cek manipulasi. Selanjutnya, subjek diminta untuk membuat keputusan terkait dengan kebijakan akuntansi mengenai biaya riset dan pengembangan. Adapun, keputusan yang dibuat berupa jawaban yang telah disediakan yaitu memilih kebijakan akuntansi yang melaporkan biaya riset dan pengembangan sebesar-besarnya atau sekecilkecilnya. Eksperimen ini kurang lebih memakan waktu \pm 15 menit.

Tahap berikutnya, subjek diminta untuk mengikuti tahap kedua dari eksperimen untuk menyelesaikan kasus dua. Subjek diminta membaca kasus kedua yang telah disiapkan, sebagaimana tahap pertama. Dalam kasus dua, informasi yang diberikan berkaitan dengan tuntutan hukum di pengadilan kepada perusahaan akibat dari penurun harga saham yang signifikan. Perusahaan diminta mengganti kerugian yang diderita investor bila perusahaan kalah di pengadilan. Selanjutnya, direktur keuangan yang memiliki wewenang untuk menggunakan judgment dalam mengestimasi setiap kondisi perusahaan, baik kalah atau menang di pengadilan, dapat mempengaruhi kebijakan akuntansinya ketika menyajikan laporan keuangan. Misalnya, apakah perusahaan akan mencatat beban kemungkinan kalah di pengdilan atau tidak. Setiap kebijakan akuntansi yang dibuat dapat mempengaruhi laba yang dilaporkan. Subjek atau direktur keuangan diberikan ringkasan penggunaan judgment mengenai adanya kemungkinan kalah di pengadilan, yaitu PSAK No. 57 tentang Kewajiban Diestimasi, Kewajiban Kontinjensi, dan Aset Kontinjensi. Setelah selesai membaca kasus, subjek diminta untuk menjawab pertanyaan yang digunakan untuk cek manipulasi. Pertanyaan tersebut terkait dengan keputusan pemilihan kebijakan akuntansi. Adapun keputusan yang dibuat berupa jawaban yang telah disediakan dalam kuesioner. Subjek diminta kepastiannya untuk melaporkan biaya kalah menghadapi tuntutan hukum ketika menyajikan laporan keuangan.
Pengambilan kebijakan untuk melaporkan biaya kalah di pengadilan dapat berdampak pada besarnya laba yang akan dilaporkan. Setiap akhir kasus yang diberikan, subjek juga diingatkan mengenai dampak dari setiap keputusan yang diambil. Tahap kedua ini diperkirakan memakan waktu \pm 15 menit.

Selanjutnya, penulis menggunakan alat analisis Anova untuk menjelaskan hasil penelitian. Selain itu melihat adanya pengaruh variable independen terhadap dependennya, Anova juga dapat melihat adanya perbedaan dalam tritmen yaitu antara pembingkaian kontrak insentif positif dengan negatif dan ada tuntutan hukum dengan tidak ada tuntutan hukum . Selain itu, melalui uji serentak maka penelitian ini juga dapat digunakan untuk melihat adanya kausalitas yang berasal dari interaksi.

\begin{tabular}{|c|c|c|c|}
\hline \multicolumn{4}{|c|}{$\begin{array}{l}\text { HASIL PENELITIAN DAN PEMBAHASAN } \\
\text { Tabel 2. Hasil Uji Pengaruh Antar Variabel }\end{array}$} \\
\hline \multicolumn{4}{|c|}{$\begin{array}{llll}\text { Kontrak } & \begin{array}{l}\text { Mean } \\
\text { Insentif }\end{array} & \text { F } & \text { Siguare }\end{array}$} \\
\hline $\begin{array}{l}\text { Kontrak } \\
\text { Insentif (K) }\end{array}$ & 65,9100 & 6,587 & 0,012 \\
\hline $\begin{array}{l}\text { Tuntutan } \\
\text { Hukum }(T)\end{array}$ & 108,018 & 10,795 & 0,001 \\
\hline $\begin{array}{l}\text { Kon Ins*Tunt } \\
\text { Hkm (K*T) }\end{array}$ & 12,541 & 1,253 & 0,266 \\
\hline
\end{tabular}

\section{Hasil Pengujian Hipotesis 1}

Hasil pengujian terhadap hipotesis 1 menunjukkan bahwa ada pengaruh pembingkaian kontrak insentif terhadap kebijakan pelaporan keuangan perusahaan, sebagaimana ditunjukkan dalam tabel 2. Hal itu dapat dilihat dari nilai signifikansi yang sebesar 0,012 (jauh dibawah 0,05 karena $\alpha=0,05$ ). Lebih lanjut, tabel 3 dan 4 menunjukkan adanya perbedaan yang signifikan antara pembingkaian kontrak insentif positif dengan pembingkaian kontrak insentif negatif. Hal itu juga dapat dilihat dari nilai signifikannya yang besarnya 0,012 juga (jauh dibawah 0,05). Dengan demikian, hipotesis 1 yang menyatakan manajemen (direktur keuangan) cenderung 
menyajikan laporan keuangan yang lebih konservatif ketika mendapat kontrak insentif yang dibingkai positif daripada kontrak insentif yang dibingkai negatif (loss) didukung.

Tabel 3. Estimasi Nilai Rata-rata (Mean) Framing

\begin{tabular}{lrrr}
\hline $\begin{array}{c}\text { Kontrak } \\
\text { Insentif }\end{array}$ & Mean & $\begin{array}{r}\text { Lower } \\
\text { Bound }\end{array}$ & $\begin{array}{c}\text { Upper } \\
\text { Bound }\end{array}$ \\
\hline Positif & 17,843 & 16,929 & 18,757 \\
\hline Negatif & 16,130 & 15,171 & 17,090 \\
\hline
\end{tabular}

Tabel 4. Perbedaan Rata-rata Keputusan Subjek Dalam Kelompok

\begin{tabular}{lllll}
\hline $\begin{array}{l}\text { Kontrak } \\
\text { Insentif }\end{array}$ & $\begin{array}{c}\text { Kontrak } \\
\text { Insentif } \\
(\mathbf{I})\end{array}$ & $\begin{array}{c}\text { Kontrak } \\
\text { Insentif } \\
\text { (J) }\end{array}$ & $\begin{array}{c}\text { Mean } \\
\text { Differen } \\
\text { ce (I-J) }\end{array}$ & Sig. \\
\hline Positif & Positif & Positif & $1,712^{*}$ & 0,012 \\
\hline Negatif & Negatif & Negatif & $-1,712^{*}$ & 0,012 \\
\hline
\end{tabular}

Dengan didukungnya Hipotesis 1 mengindikasikan bahwa manajemen (direktur keuangan) ketika insentifnya dibingkai secara positif (gain) terbukti bersikap lebih hati-hati (risk averse) dengan membuat kebijakan yang cenderung konservatif ketika menyajikan laporan keuangan. Sebaliknya, kontrak insentif yang dibingkai loss (negatif) cenderung membuat kebijakan akuntansi yang kurang konservatif ketika menyajikan laporan keuangan karena kontrak insentif negatif menempatkan individu tersebut dalam posisi loss sehingga ia semakin berani mengambil risiko. Hal itu membuktikan bahwa teori prospek melalui penjelasan framing effect dapat digunakan untuk menjelaskan manajemen (direktur keuangan) dalam mengambil kebijkakan akuntansi dalam pelaporan keuangan perusahaan. Hasil ini mendukung beberapa penelitian sebelumnya, baik di bidang ekonomi, politik, hukum, kedokteran, dan sebagainya. Teori prospek juga menjelaskan bahwa dalam mengambil keputusan individu mengevaluasi opsi keputusan relatif dengan beberapa reference point, status quo atau kondisi pada saat mengambil keputusan (Guthrie, 2012).

\section{Hasil Pengujian Hipotesis 2}

Hasil pengujian terhadap Hipotesis 2 juga dapat dilihat dalam Tabel 2. Tabel tersebut juga menunjukkan pengaruh tuntutan hukum terhadap kebijakan akuntansi manajemen (direktur keuangan) ketika menyajikan laporan keuangan. Hal itu dapat dilihat dari nilai signifikanya yang sebesar 0,001 (sangat jauh dari 0,05 ). Selain itu, hasil penelitian ini juga menunjukkan adanya perbedaan keputusan antara perusahaan ada tuntutan hukum dengan yang tidak ada tuntutan hukum. Dengan demikin, Hipotesis 2 yang menyatakan bahwa ketika ada tuntutan hukum, manajemen (direktur keuangan) cenderung menyajikan laporan keuangan yang lebih konservatif daripada ketika tidak ada tuntutan hukum didukung. Sedangkan, untuk menunjukkan adanya perbedaan keputusan antara perusahaan yang ada tuntutan hukum dengan yang tidak ada tuntutan hukum dapat dilihat dalam Tabel 5 dan 6 .

Berdasarkan hasil pengujian Hipotesis 2 tersebut membuktikan bahwa manajemen (direktur keuangan) yang sedang mendapat tuntutan hukum dari masyarakat (investor) cenderung lebih berhati-hati dengan menyajikan laporan keuangan yang konservatif melalui kebijakan akuntansi yang segera membebankan biaya kemungkinan kalah di pengadilan. Meskipun kondisi tersebut belum terjadi, namun karena ada indikasi bahwa perusahaan dapat mengalami kekalahan dalam mengahadapi tuntutan hukum investor di pengadilan, manajemen (direktur keuangan) memilih untuk segera mencatat biaya tersebut sebesar probabilitasnya. Kebijakan manajemen, yang segera mencatat biaya kemungkinan kalah di pengadilan, tersebut berimplikasi pada mengecilnya laba yang akan dilaporkan. Hal itu menunjukkan bahwa laba yang kecil lebih disukai daripada laba yang besar tetapi masih mungkin harus menanggung 
biaya di masa mendatang. Sikap manajemen tersebut sesuai dengan penjelasan certainty effect dalam teori prospek.

Dengan demikian, teori prospek, melalui penjelasan certainty effect dapat digunakan untuk menjelaskan alasan manajemen (direktur keuangan) membuat keputusan pelaporan keuangan yang konservatif. $\mathrm{Hal}$ ini melengkapi hasil penelitian sebelumnya, khususnya penelitian yang telah menggunakan teori prospek dalam menjelaskan factor psikologis pengambil keputusan, antara lain Sitkin dan Weingart (1995), Liu dan Thornton (2008), Watts (2003), dan Beaver (1993).

\section{Hasil Pengujian Hipotesis 3}

Hipotesis 3 yang dibangun atas dasar fenomena praktis menunjukkan hasil yang tidak didukung. Hal itu dapat dilihat dalam tabel 2 , dalam baris $\left(\mathrm{K}^{*} \mathrm{~T}\right)$ yang menunjukkan angka yang tidak signifikan yaitu 0,266 (jauh di atas 0,05$)$. Hipotesis 3 menginteraksikan antara variable pembingkaian kontrak insentif dengan tuntutan hukum. Dugaan peneliti bahwa manajemen akan semakin konservatif ketika dalam posisi gain (karena kontrak insentifnya dibingkai positif) dan ada tuntutan hukum tidak didukung. Perbedaan nilai mean untuk variable pembingkaian kontrak insentif baik negatif (loss) dengan tidak ada tuntutan hukum maupun ada tuntutan hukum tinggi dengan nilai mean untuk pembingkaian positif (gain) dengan tidak ada tuntutan hukum maupun ada tuntutan hukum, seperti yang nampak pada Tabel 6. Hal itu dapat menjelaskan mengapa interaksi tersebut tidak signifikan.

\section{PENUTUP}

Setelah mengetahui hasil pengujian hipotesis dan pembahasannya, maka penulis dapat menyimpulkan sebagai berikut. Pertama, ada pengaruh pembingkaian kontrak insentif terhadap pengambilan kebijakan akuntansi yang dilakukan oleh manajemen (direktur keuangan) ketika menyajikan laporan keuangan. Hasil tersebut menunjukkan bahwa teori prospek dapat digunakan untuk untuk menjelaskan keputusan dalam ranah akuntansi melalui penjelasan framing effect. Direktur keuangan yang mendapat kontrak insentif yang dibingkai positif cenderung lebih berhati-hati (risk averse) dengan membuat laporan keuangan yang lebih konservatif daripada direktur keuangan yang kontrak insentifnya dibingkai negatif (risk taker). Kedua, adanya tuntutan hukum terhadap perusahaan membuat manajemen (direktur keuangan) cenderung menyajikan laporan keuangan yang lebih konservatif daripada yang tidak sedang mendapat tuntutan hukum. Direktur keuangan cenderung melaporkan kemungkinan kalah di pengadilan sebagai biaya meskipun berdampak pada laba yang mengecil daripada menyajikan laba yang besar tetapi masih ada kemungkinan harus membayar kekalahan di pengadilan. Hal itu menunjukkan bahwa teori prospek dapat digunakan untuk menjelaskan alasan manajemen menyajikan laporan keuangan yang konservatif melalui penjelasan certainty effect. Ketiga, interaksi antara pembingkaian kontrak insentif dan tuntutan hukum yang diduga ada pengaruh yang semakin kuat tidak terdukung.

Selanjutnya, pepatah mengatakan bahwa tak ada gading yang tak retak juga berlaku dalam penelitian ini. Ada beberapa keterbatasan dalam penelitian ini, antara lain pertama, terkait dengan ukuran kinerja yang digunakan dalam dalam membuat kasus pembingkaian. Ukuran kinerja yang digunakan hanya untuk kinerja yang berada di atas batas minimum menerima bonus tetapi tidak mencapai target maksimal. Akibatnya, penelitian ini tidak dapat mengetahui sikap manajemen yang kinerjanya melebih target yang ditetapkan atau malah yang tidak dapat mencapai target minimum menerima bonus. Oleh karena itu, saran ke depan agar penelitian mendatang membuat ukuran kinerja yang lebih komprehensif. Kedua, terkait dengan penggunaan mahasiswa sebagai penyulih manajemen (direktur keuangan). Penggunaan mahasiswa dalam eksperimen ini diduga dapat mengancam validitas eksternal. Mahasiswa 
yang kemampuan dan pengetahuannya masih terbatas dapat menjadikan hasil penelitian kurang dapat digeneralisasi ke populasinya. Oleh karena itu, penelitian mendatang diharapkan dapat menggunakan subjek yang berasal dari praktis yang sesungguhnya dan mahasiswa, sehingga dapat diketahui adanya perbedaan yang diduga dapat mengancam validitas eksternalnya. Ketiga, penelitian ini tidak dapat membuktikan adanya pengaruh interaksi antara variable pembingkaian kontrak insentif dengan variable tuntutan hukum. Pengukuran diduga mempengaruhi hubungan yang tidak signifikan tersebut, sehingga menyebabkan keterbatasan dalam penelitian ini. Oleh karena itu, peneliti yang akan datang diharapkan mampu memperbaiki pengukuran yang telah dilakukan dalam penelitian ini.

\section{REFERENSI}

Ahmed, A., et. al. (2000). Accounting Conservatism and the Valuation of Accounting Numbers: Evidence on the Feltham-Ohlson (1996) Model. Journal of Accounting, Auditing, and Finance. 15, 271-292.

Beaver, W. H., and S. G. Ryan. (2005). Conditional and unconditional conservatism: Concepts and modeling. Review of Accounting Studies. 10, 269309.

Beaver, W.H. (1993). Conservatism, Working Paper. Stanford University.

Church, Libby, and Zhang. (2008). Contracting Frame and Individual Behavior: Experimental Evidence Journal of Management. Accounting Research. 22, 153-168

Guthrie, C. (2012). Prospect Theory, Risk Preference \& the Law. Working Paper.

Hair, J.F., et. al. (1998). Multivariate Data Analysis; With Readings. Fourth Edition. McMillan: Publishing Company.

Hannan, R. L., et. al. (2005). Bonus versus penalty: Does contract frame affect employee effort? In Experimental Business Research. Edited by A. Rappaport and R. Zwick. Vol. II, Warren, MI: Springer Science and Business Media.

Healy, P. and Palepu, K. (1993). The effect of firms' financial disclosure strategies on stock prices. Accounting Horizons. 7, 111.

Hellman, N. (2008). Accounting Conservatism under IFRS. Accounting in Europe. 5, 71-100, 200.

Huijgen, C. and Lubberink, M. (2001). Earnings Conservatism, Litigation, and Contracting: The Case of Cross-Listed Firms. Working paper.

International Accounting Standards Board. (2006). International Financial Reporting Standards 2006 Bound Volume. London: International Accounting Standards Committee Foundation.

Jamal, K. et. al. (2005). Detecting Framing Effect in Financial Statements. Contemporar Accounting Research. 12, I.

Johnson, Paul e; et. el. (1991). Effects of Framing on Auditor Decisions. Organizational Behavior And Human Decision Processes. 50, 75-105.

Kahneman, D. (2003). Maps of bounded rationality: Psychology for behavioral economics. American Economic Review. 93, 1449-1475.

Kahneman, D., and Tversky, A. (1979). Prospect Theory: An Analysis of Decision Under Risk. Econometrica. 47, 263-291.

Kahneman, D., et. al. (1986). Fairness and the Assumptions of Economics. Journal of Business. 59, 285-300.

Kothari, S.P., et.al. (1998). Capitalization versus Expensing: Evidence on the Uncertainty of Future Earnings from Current Investments in PP\&E versus R\&D. Fortcoming

Lubberink, M., and Huijgen C. (2001). A wealthbased explanation for earnings 
conservatism. European Finance Review. 5, 323-349.

Luft, J. (1994). Bonus and penalty incentives: Contract choice by employees. Journal of Accounting and Economics. 18, 181206.

March, J., and Z. Shapira. (1992). Variables Risk Refer- ences and the Focus of Attention. Psych. Rev. 99, 172-83.

Nahartyo, Ertambang. (2012). Desain dan Implementasi Riset Eksperimen. 1 ed. Yogyakarta, Indonesia: UPP STIM YKPN

Sekaran, U. (2003). Research Methods for Business: A Skill Building Approach, Fourth edition. New York, US: John Willey \& Sons, Inc.
Sitkin, S. B., and Weingart, L. R. (1995). Determinants of risky decision-making behavior: A test of the mediating role of risk perceptions and propensity. The Academy of Management Journal. 38, 1573-1592.

Watts, R.L. (2003a). Conservatism in Accounting Part I: Explanations and Implications. University of Rochester. Working Paper.

(2003b). Conservatism in Accounting Part II: Evidence and Research opportunities The Bradley Policy Research Center Financial Research and Policy. University of Rochester. Working Paper 